\title{
FIZIKALNI MODEL PROCJEĐIVANJA VODE KROZ POROZNI MATERIJAL
}

\author{
PHYSICAL MODEL OF WATER SEEPAGE \\ THROUGH POROUS MEDIUM
}

\author{
Iva Reinić ${ }^{*}$, Elvis Žic ${ }^{*}$
}

\begin{abstract}
Sažetak
U ovom radu opisana su osnovna načela $i$ vladajuće jednadžbe za opis strujanja podzemne vode kroz porozni materijal. U svrhu dobivanja mjerodavnih vrijednosti pojedinih karakterističnih fizikalnih veličina kod strujanja podzemne vode $u$ pjeskovitom poroznom materijalu (brzina procjeđivanja, ekvipotencijal u određenoj točki unutar prostora, hidraulički gradijenti, protok i sl.) korišten je fizikalni model GUNT HM169 koji čini sastavni dio hidrotehničkog laboratorija Građevinskog fakulteta Sveučilišta u Rijeci. U radu je opisan princip rada za navedeni fizikalni model te način pripreme samih eksperimentalnih pokusa. U tom pogledu, izrađeno je nekoliko hidrodinamičkih analiza strujanja podzemne vode u odnosu na varijabilnost potencijala gornje i donje vode, analiza strujanja ispod vertikalnog čeličnog žmurja (dijafragme) te analiza opstrujavanja podzemne vode ispod prostorno trapezno izmodelirane prirodne nasute brane. Za potrebe provođenja pokusa, nasuta brana ručno je izrađena od pleksi stakla. Svrha istraživanja kroz fizikalni model HM169 bila je dobivanje jasnije slike strujnog polja ispod pojedinih hidrotehničkih objekata $i$, posljedično, dobivanje simulacijskih prikaza propagacije toka podzemne vode koja je praćena žutim fluorescin traserom.
\end{abstract}

Ključne riječi: procjeđivanje vode, Darcyeva brzina, potencijalno strujanje, strujna mreža, hidraulički gradijent, fizikalni model, hidraulička analiza

\begin{abstract}
This paper describes basic principles and governing equations for describing groundwater flow through porous material. In order to obtain the relevant values of some of the characteristic physical quantities of groundwater flow in the sandy porous material (infiltration velocity, equipotential at a certain point within the space, hydraulic gradients, flow, etc.), the physical model GUNT HM169 was used, which is an integral part of the hydro technical laboratory of the Faculty of Civil Engineering,
\end{abstract}

\footnotetext{
* Sveučilište u Rijeci, Građevinski fakultet, Radmile Matejčić 3, 51000 Rijeka E-mail: iva.reinic@student.uniri.hr; elvis.zic@uniri.hr
} 
University of Rijeka. The paper describes the working principle for the mentioned physical model and the preparation of the experimental trials themselves. In this respect, several hydrodynamic analyzes of groundwater flow regarding the upper and lower water variability potential were made as well as the flow analysis below the vertical steel diaphragm and the analysis of groundwater depletion under the spatially trapezoidal modified natural sloping dam. To carry out the experiment, the sloping dam was manually made of Plexiglas. The purpose of the research through the physical model HM169 was to obtain a clearer picture of the streamline field below the individual hydroelectric objects and consequently to obtain a simulation of the propagation of the groundwater flow which was followed by a yellow fluorescence tracer.

Key words: water infiltration, Darcy's speed, potential flow, equipotential network, hydraulic gradient, physical model, hydraulic analysis

\section{Uvod}

Procjeđivanje vode označava postupak propuštanja vode kroz poroznu sredinu, tj. filtarski materijal. Analiza procjeđivanja vode ispod brane $\mathrm{u}$ praksi se može primijeniti pri rješavanju mnogobrojnih problema - kod određivanja sile uzgona na temelje brane, određivanja stabilnosti objekta uslijed mogućeg diferencijalnog slijeganja, iscrtavanja strujnih polja i mreža ispod brane i slično. Potencijalno strujanje pojam je koji opisuje kretanje neviskoznih tekućina u kojima neće doći do vrtložnog strujanja. Usprkos očiglednom odstupanju od ponašanja realne tekućine, $u$ većem dijelu konvergentnog strujnog polja realne tekućine opravdano je usvajanje pretpostavki o bezvrtložnosti i neviskoznosti [1]. Potencijalno strujanje nestlačivog fluida opisano je jednadžbama:

$$
u=\frac{\partial \phi}{\partial x} \quad v=\frac{\partial \phi}{\partial y}
$$

gdje su $u$ i $v$ komponente dvodimenzionalnog strujanja $\mathrm{u}$ Kartezijevom sustavu. Linije koje povezuju točke istog potencijala (oznaka $\phi$ ) nazivaju se ekvipotencijale. U strujnom polju nestišljive tekućine vrijedi sljedeća jednadžba kontinuiteta:

$$
\operatorname{div} \vec{v}=0
$$

Uvođenjem izraza (1) u (2) dobiva se Laplaceova diferencijalna jednadžba:

$$
\frac{\partial^{2} \phi}{\partial x^{2}}+\frac{\partial^{2} \phi}{\partial y^{2}}=0
$$

Laplaceova jednadžba opisuje i strujnu mrežu koja je sastavljena od strujnica i ekvipotencijala koje su međusobno okomite u slučaju izotropnog koeficijenta propusnosti. Strujne linije se mogu opisati i funkcijom $\psi(\mathrm{x}, \mathrm{y})$ 
koja će zbog uvjeta okomitosti definirati vrijednost komponenti brzina u strujnom polju:

$$
u=\frac{\partial \Psi}{\partial y}, v=-\frac{\partial \Psi}{\partial x}
$$

Uzduž strujnice neće doći do promjene strujne funkcije, što znači da nema protjecanja kroz njenu konturu. Potencijalnim strujanjem pretpostavljena je bezvrtložnost koja se može definirati izrazom:

$$
\operatorname{rot} \vec{v}=0, \frac{\partial u}{\partial y}-\frac{\partial v}{\partial x}=0
$$

Strujanje će biti potencijalno ako su u svim točkama elementa ispunjenog tekućinom zadovoljene sljedeće jednadžbe:

$$
\frac{\partial u_{z}}{\partial y}=\frac{\partial u_{y}}{\partial z} ; \quad \frac{\partial u_{y}}{\partial x}=\frac{\partial u_{x}}{\partial y} ; \quad \frac{\partial u_{x}}{\partial z}=\frac{\partial u_{z}}{\partial x}
$$

gdje su $u_{x}, u_{y}$ i $u_{z}$ komponente brzine tekućine i sve se mogu izraziti kao parcijalne derivacije $s$ negativnim predznakom kako slijedi u nastavku [2, 3]:

$$
u=-\frac{\partial \phi}{\partial x}, \quad v=-\frac{\partial \phi}{\partial y}, \quad w=-\frac{\partial \phi}{\partial z}
$$

Funkcija $\phi$ naziva se brzinski potencijal. Plohe tekućine kod kojih je u svim točkama ista vrijednost potencijala nazivaju se ekvipotencijalne plohe ili plohe istog potencijala. Iz geometrije proizlazi da su vektori brzine čestica normale na ekvipotencijalne plohe, a s obzirom na to da su vektori brzina tangencijalni na strujnice, zaključuje se da su strujnice okomite na ekvipotencijalne plohe kod izotropnog polja koeficijenta propusnosti. Sve čestice gibaju se brzinama okomito usmjerenim na ekvipotencijalne plohe i pri tome ne rotiraju. Potencijal brzine mora zadovoljavati Laplaceovu jednadžbu koja glasi [4]:

$$
\frac{\partial^{2} \phi}{\partial x^{2}}+\frac{\partial^{2} \phi}{\partial y^{2}}+\frac{\partial^{2} \phi}{\partial z^{2}}=0
$$

Formula za Darcyjevu brzinu filtracije na koordinatnim osima glasi:

$$
\begin{array}{ll}
u=-\frac{\partial(k H)}{\partial x} & v=-\frac{\partial(k H)}{\partial y} \quad w=-\frac{\partial(k H)}{\partial z} \\
H=z+\frac{p}{\gamma} &
\end{array}
$$

pri čemu fizikalna veličina $H$ definira ukupnu specifičnu potencijalnu energiju (suma potencijalne energije položaja $z$ i specifične potencijalne energije tlaka $p / \rho g$ ). Koeficijent $k$ predstavlja koeficijent filtracije, vodopropusnosti ili procjeđivanja i ima dimenziju brzine. Na temelju formule filtracije koja se izražava u obliku parcijalnih derivacija funkcije $k H$, 
zaključuje se da je filtracija potencijalno bezvrtložno gibanje s potencijalom brzine koji glasi [1]:

$$
\Phi(x, y, z)=k H
$$

\section{Općenita razmatranja gibanja podzemne vode}

Gibanje podzemne vode opisano je kao gibanje tekućine i plina u poroznoj sredini, a samo gibanje tekućine u poroznoj sredini naziva se filtracijom. Filtracija ima posebnu ulogu u hidrotehničkih građevinama jer nam njeno poznavanje omogućava rješavanje raznih problema hidrotehničkih građevina - stabilnost brana, položaj podzemne vode, filtraciju iz kanala i odvodnju tla [2]. Voda se u poroznoj sredini može nalaziti u različitim oblicima kao: 1) adhezijska voda - razina podzemne vode u kojoj se ona nalazi u porama ali se drži samo na kontaktima između zrna materijala tla, 2) kapilarna voda - područje u kojem su većinom sve pore ispunjene vodom te 3) gravitacijska voda - razina u kojoj su sve pore ispunjene vodom te na njih djeluje sila teža [5].

Podzemna se voda kroz pore tla uslijed djelovanja gravitacije spušta sve do vodonepropusnog sloja nakon čega slijedi pretežno horizontalno strujanje. Ukoliko se proces procjeđivanja ne mijenja tijekom vremena, promatra se tzv. stacionarno tečenje vode, a ukoliko podzemni tok ulazi u vodopopusni sloj koji je ograničen nepropusnim slojem s gornje i donje strane i ispunjava sve pore propusnog sloja, tada se stvara tlak koji je veći od atmosferskog i nastaje gibanje podzemne vode pod tlakom [5]. Voda se kroz sitno tlo procjeđuje veoma sporo, tj. s malim Reynoldsovim brojem Re te se za strujanje podzemne vode usvaja laminarno strujanje.

Zakon laminarne filtracije (Darcyev zakon) tvrdi kako je brzina toka vode linearno proporcionalna hidrauličkom gradijentu (Slika 1.):

$$
v=k I=k \frac{\Delta h}{\Delta l}
$$

U izrazu (12) simbol $v$ definira Darcyevu brzinu $[\mathrm{m} / \mathrm{s}], \quad I$ je pad piezometarske linije [/], $\Delta h$ razlika potencijala između dva piezometra [m], $k$ je koeficijent filtracije [m/s], dok je $\Delta l$ razmak između dva piezometra [m].

Hidraulički pad je kod postepeno promjenjivog gibanja podzemne vode konstantna veličina pa su zbog toga brzine filtracije u svim točkama homogenog tla jednake [2]:

$$
u=-k \frac{d H}{d l}
$$

gdje je $d l$ udaljenost između dva presjeka strujnice, [m], a $d H$ pad tlaka između dva presjeka strujnice, [Pa]. Kod izotropnog koeficijenta filtracije segment strujne mreže sa susjednim ekvipotencijalama i strujnicama 
pravokutnog je oblika, što označava da je srednja brzina filtracije $v$ jednaka brzini $u$ :

$$
u=-k \frac{d H}{d l}=k I
$$

gdje I označava pad piezometarske linije (ili plohe) koji je promjenjiv uzduž toka. Kao temelj proračuna za postepeno promjenjivo gibanje podzemne vode uzima se srednja brzina filtracije (izraz (12)), iako to nije najtočnije jer je Darcyeva brzina u stvari protok kroz jediničnu površinu.

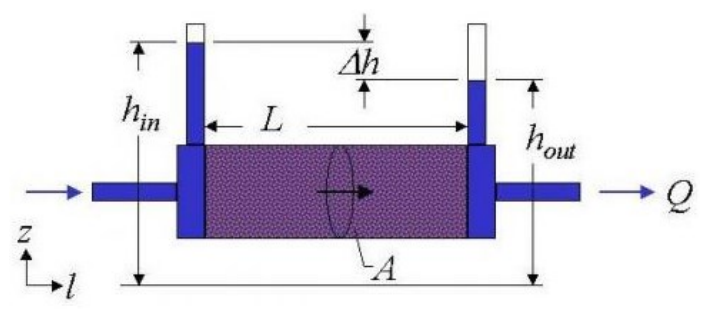

Slika 1. Darcyev eksperiment [6]

$\Delta h$ - promjena potencijala, $A$ - površina poprečnog presjeka cijevi (filtarskog sloja), $L$ - duljina promatranog odsječka cijevi, $Q$ - količina vode koja protječe kroz filterski sloj

U hidrotehnici se općenito promjenjivo gibanje podzemnih voda može susresti kod filtracije ispod hidrotehničkih građevina. Područje podzemnog toka je tada ograničeno donjim vodonepropusnim slojem na određenoj dubini i gornjim vodonepropusnim dijelom građevine. Temelj brane i dno vodonosnog sloja nepropusni su tako da imaju prirodan uvjet koji zadovoljava nultu liniju toka, ali ih također možemo smatrati i rubnim strujnicama. Geometrijski oblik hidrodinamičke mreže neće se mijenjati promjenom hidrostatskog tlaka niti koeficijenta filtracije kod izotropnog strujanja. Mijenjati će se samo brzina filtracije i protok, ali gibanje ostaje po istim trajektorijama. Ukupan protok kroz mrežu dan je izrazom [3, 7]:

$$
q=\Delta q m=k \frac{m}{n} H
$$

Nove fizikalne veličine u gornjoj formulaciji su $m$ broj trajektorija [/], te $n$ broj kvadrata u trajektorijama [/].

\section{Fizikalni model HM169}

Fizikalni model HM169 eksperimentalni je uređaj za hidrauličku analizu procjeđivanja vode i izračun tlakova u pojedinim točkama kod različitih hidrotehničkih građevina. U pokusima koje su provođeni testirana su ponašanja podzemnih tokova na primjerima drenažnog jarka, prirodno 
formirane brane, žmurja, temelja brane i vertikalne pregrade uz varijabilnost razina gornje i donje vode na fizikalnom modelu. Na Slici 2. prikazan je fizikalni model i svi njegovi dijelovi. Prilikom rada u hidrotehničkom laboratoriju bilo je potrebno napuniti radnu sekciju poroznim materijalom (finozrnatim morskim pijeskom) te spremnik vodom. Sa svake strane fizikalnog modela (na spremnicima gornje i donje vode) postavljene su trake krojačkog metra pomoću kojih se moglo olakšano očitavati razine vode u gornjem i donjem spremniku tijekom mjerenja na određenim pokusima. Sami proces punjenja spremnika za vodu na fizikalnom modelu HM169 je detaljno opisan u radu [6].

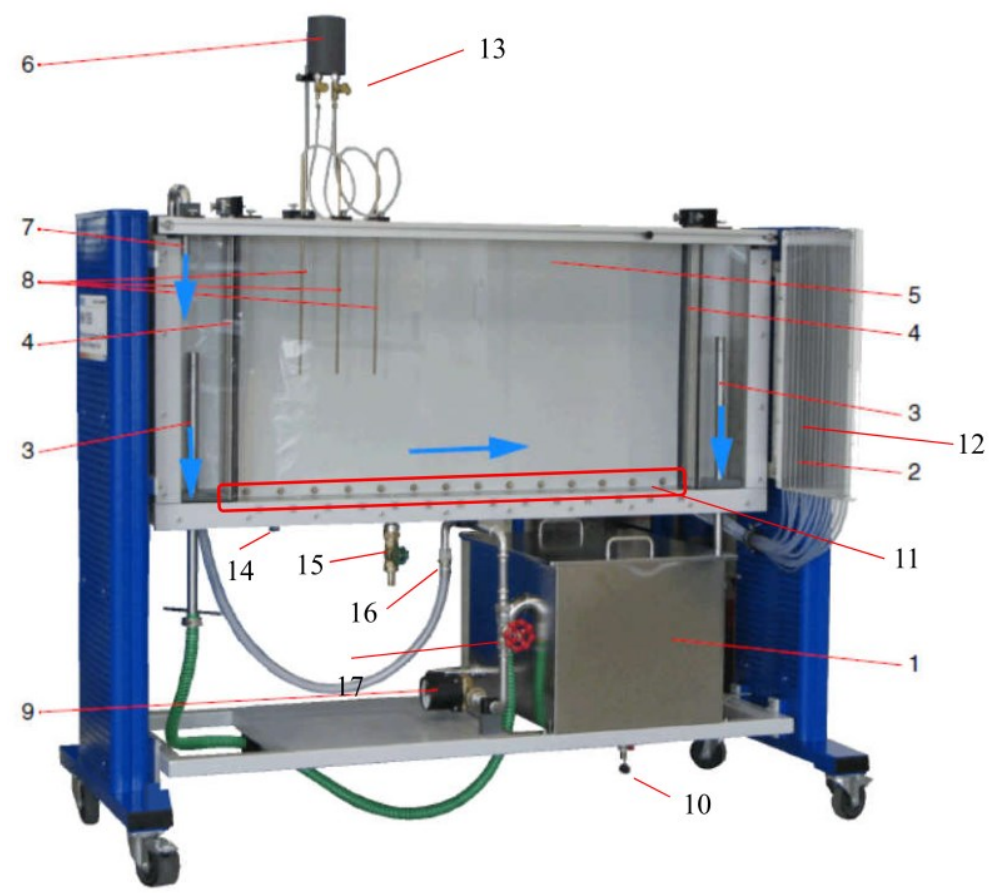

Slika 2. Fizikalni model HM169 i njegovi dijelovi $[6,7]$

1 - spremnik za vodu, 2 - piezometarska harfa sa 14 manometarskih cijevi,

3 - preljevna cijev, 4 - granična ploča, 5 - eksperimentalni spremnik (eksperimentalna radna sekcija), 6 - spremnik za boju, 7 - ulazni otvor, 8 - injektirajuće cijevi za boju, 9 - pumpa, 10 - ventil za odvod vode iz spremnika, 11 - točke mjerenja tlaka, 12 - prekidač pumpe, 13 - 3 ventila spremnika za boju, 14 - poklopac za odstranjivanje pijeska, 15 - odvodni ventil eksperimentalnog spremnika, 16 - nepovratni ventil, 17 - ulazni ventil za dovod vode prema fizikalnom modelu 
Punjenje spremnika za boju provodi se na sljedeći način (Slika 2.):

1. zatvoriti 3 ventila na spremniku za boju

2. uliti otprilike $500 \mathrm{ml}$ vode u spremnik za boju (kapacitet je $500 \mathrm{ml}$ )

3. izvaditi injekcijske cijevi iz eksperimentalne radne sekcije fizikalnog modela i pustiti ih da slobodno vise kako bi se pročistili od boje

4. otvoriti ventile za boju na injekcijskim cijevima

5. promiješati jednu malu žličicu fluorescentnog praha (tzv. fluorescina - koristi se kao boja za tragove linija protoka podzemne vode) s $500 \mathrm{ml}$ vode i uliti u spremnik za boju

6. pozicionirati injekcijske cijevi i otvoriti lagano ventile za ispuštanje boje (naglo otvaranje ventila rezultira formiranjem velike širine strujnice - valja biti oprezan i strpljiv pri radu).

Prije rada sa piezometarskom harfom potrebno je provjeriti sljedeće:

1. ukoliko su prisutni balončići zraka, potrebno je isprati cijevi (skidanjem cijelog dijela piezometarske harfe i njenim nakošenjem; ili pak ispuhivanjem svake cijevi kompresorom (bolja varijanta))

2. eksperimentalna radna sekcija se treba napuniti vodom do minimalno $10 \mathrm{~cm}$ visine. Sve točke mjerenja (na pozicijama mjernih piezometara) moraju se nalaziti ispod razine vode u radnoj sekciji.

3. provjeriti ispravnost očitanja razina vode na svakom piezometru unutar piezometarske harfe ukoliko vrijednosti očitanja razina vode u piezometrima ne zadovoljavaju treba još jednom piezometasku harfu podignuti (skinuti sa nosivih vijaka) te iscijediti svu preostalu vodu. Nakon toga se može započeti sa mjerenjima.

\subsection{Primjena fizikalnog modela HM169}

Na fizikalnom modelu HM169 provode se mjerenja i istraživanja ponašanja procjeđivanja vode na primjerima drenažnog jarka, prirodno formirane brane, žmurja, temelja brane i vertikalne pregrade uz primjenu različitih razina vode u spremniku gornje vode.

I. Drenažni jarak (procjeđivanje kroz porozni materijal)

U ovom pokusu cilj je upoznati se s drenažom kroz porozni materijal, odrediti linije protoka (strujnice) i razviti ekvipotencijalnu mrežu. Pokus se provodi tako da se u eksperimentalni spremnik (eksperimentalnu radnu sekciju) nanese pijesak do $500 \mathrm{~mm}$ visine od dna te se preljevna cijev u spremniku gornje vode namjesti na $450 \mathrm{~mm}$ visine od dna, dok se razina vode u donjem spremniku postavi na $100 \mathrm{~mm}$. Zatim se uključi pumpa za vodu i čeka se dok se protok ne ustali. Nakon stabilizacije protoka otvaraju se 3 ventila injekcijskih cijevi za boju te se promatraju i dokumentiraju linije protoka (strujnice). Dobivene strujnice prikazane su na Slici 3.a). 
Iz Slike 3.a) se može zaključiti kako je procjeđivanje kroz porozni materijal popraćeno padom potencijalne energije tlaka uzduž toka, odnosno jasno je vidljivo kako hidraulički gradijent $I=\mathrm{d} H / \mathrm{d} l$ između dvije razine gornje i donje vode postepeno raste uzduž toka. Najveći hidraulički gradijent se javlja pri samom izlazu vode u donji spremnik. Što je veći hidraulički gradijent, to je prema Darcyevom zakonu procjeđivanja za homogeni materijal veća brzina filtracije $\left(v=k^{*} I\right)$.
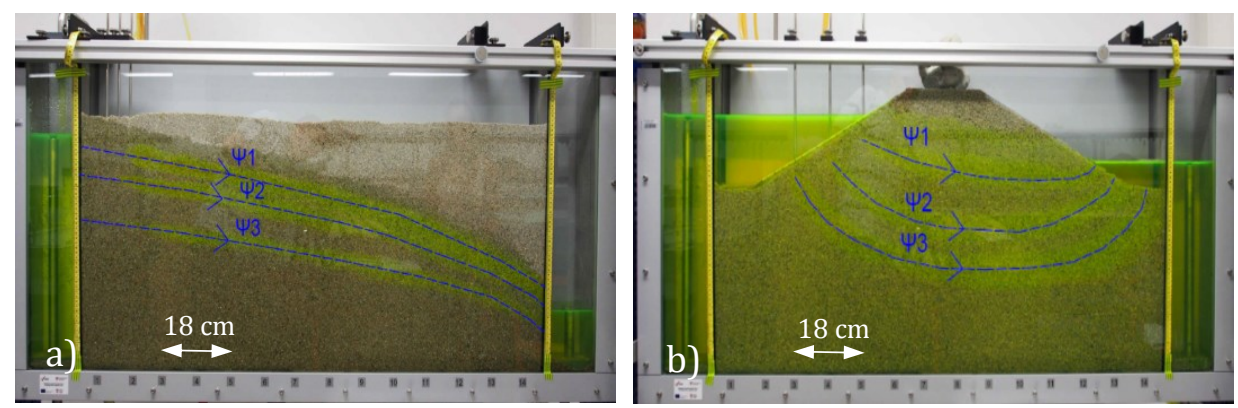

Slika 3. Prikaz strujnica u pokusu sa a) drenažnim jarkom i b) nasipom (branom) od prirodnog materijala [6]

II. Nasip (brana) od prirodnog materijala

U pokusu sa branom cilj je odrediti strujnice i razviti ekvipotencijalnu mrežu. Prilikom izrade pokusa bilo je potrebno izraditi model brane od poroznog materijala tj. pijeska nagiba pokosa 1:2 (Slika 3.b)). Za mjerodavnu izradu brane sa svim potrebnim geometrijskim veličinama izrađen je pomoćni model od pleksiglasa sa zglobovima koji je dodatno perforiran sa rupicama na stijenkama kako bi se voda mogla slobodno procjeđivati kroz tako formirani prirodni nasip. Nakon uspješne izrade brane, pozicionirane su injektirajuće cijevi za ispuštanje boje s lijeve strane pokosa modela te je pokrenuta pumpa za vodu. Nakon što se protok ustalio, otvoreni su ventili za ispuštanje fluorescina kako bi se dobile jasno vidljive strujnice (Slika 3.b)).

\section{III. Čelično žmurje}

Zadatak ovog pokusa bio je odrediti protočne linije ispod čeličnog žmurja, razviti strujnu mrežu te odrediti pritiske vode na dnu eksperimentalne radne sekcije. Eksperiment se provodi tako da se u porozni materijal namjesti model žmurja i fiksira na vrh eksperimentalne radne sekcije. Debljina sloja pijeska je jednolika i nalazi se na $300 \mathrm{~mm}$ iznad dna eksperimentalne radne sekcije. Provedeno je 5 različitih pokusa uz promjenu visine preljevne cijevi u lijevoj i desnoj komori (spremniku gornje i donje vode) te promjenu visine žmurja od dna eksperimentalne radne sekcije. Na Slici 4.a) prikazan je pokus s dobivenim strujnicama na kojem je visina preljevne cijevi u lijevom spremniku gornje vode iznosila $530 \mathrm{~mm}$, a 
u desnom spremniku donje vode $350 \mathrm{~mm}$. Visina žmurja je iznosila $90 \mathrm{~mm}$ od dna eksperimentalne radne sekcije.

U pokus 3.4. razina vode na preljevnoj cijevi u desnom spremniku gornje vode iznosila je $450 \mathrm{~mm}$, a razina preljevne cijevi u desnom donjem spremniku je uzeta sa $350 \mathrm{~mm}$ (Slika 4.b)). Visina žmurja od dna iznosila je $150 \mathrm{~mm}$. Iz Slike 4. se može vidjeti kako se strujnice mijenjaju promjenom razine gornje i donje vode te visine žmurja postavljene u odnosu na dno eksperimentalne radne sekcije.
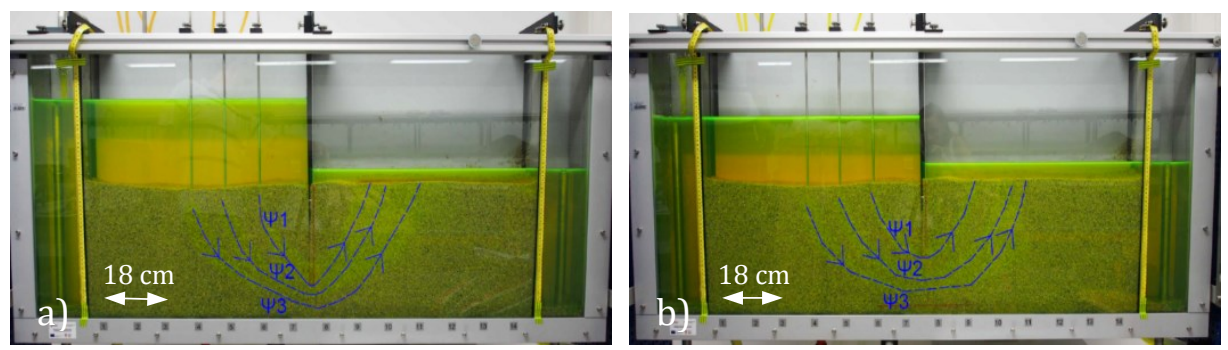

Slika 4. Prikaz strujnica kod a) Eksperimenta 3 - čelično žmurje te

b) Eksperimenta 3.4. - čelično žmurje [6]

IV. Čelično žmurje sa ugrađenim piezometrima

Cilj ovog pokusa bio je odrediti pritiske u piezometrima na samom žmurju te posljedično $s$ time iscrtati dijagram opterećenja na stijenke žmurja sa unutarnje i vanjske strane. Pokus je proveden na način da se zamijenilo žmurje iz prethodnog pokusa sa žmurjem koje na sebi ima ugrađene piezometre za određivanje, odnosno prikaz pritisaka (Slika 5.).

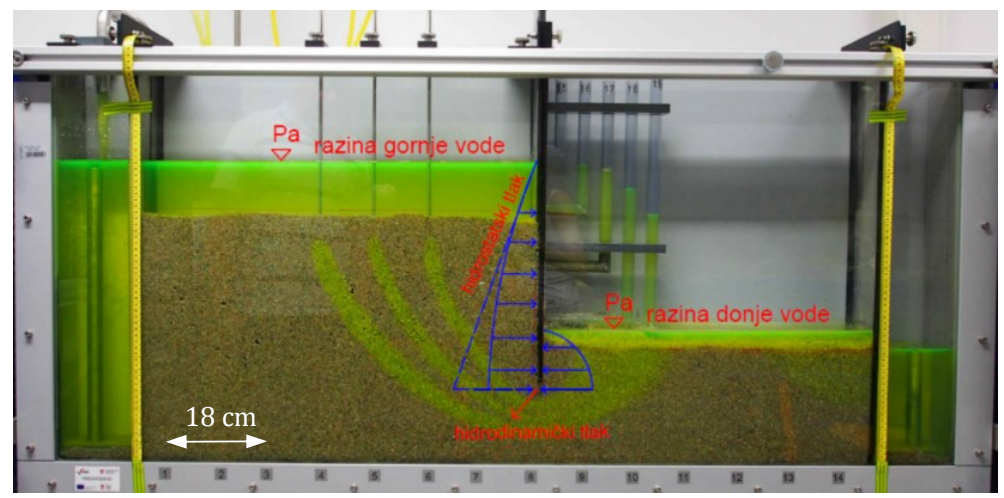

Slika 5. Eksperiment 4 - žmurje sa ugrađenim piezometrima - odnos hidrostatskog i hidrodinamičkog tlaka na pokusu s čeličnim žmurjem [6]

Izvedena su tri pokusa sa izmjenama razina vode u gornjem spremniku te visinama žmurja postavljenim od dna spremnika. Na Slici 5. je prikazan 
Eksperiment 4 sa iscrtanim strujnicama kod kojeg je razina vode u gornjem lijevom spremniku iznosila $500 \mathrm{~mm}$, a u desnom donjem spremniku 200 $\mathrm{mm}$. Visina otvora žmurja od samog dna eksperimentalne radne sekcije iznosila je $100 \mathrm{~mm}$. Sa Slike 5. je vidljivo kako je tlak najviši u prvom piezometru (broj 16), a najniži u zadnjem (broj 19), iz čega se zaključuje kako se hidrodinamički pritisak postepeno smanjuje po dubini u odnosu na hidrostatski pritisak koji se kod mirujućeg sustava linearno povećava po dubini po Pascalovom zakonu.

\section{Temelj brane}

Cilj Pokusa 5 bio je odrediti dijagram (profil) pritiska vode na temelj brane s obzirom na dubinu čeličnog žmurja, odnosno njegovu poziciju od dna eksperimentalne radne sekcije. Porozni materijal namješten je na visinu od $300 \mathrm{~mm}$ od dna eksperimentalne radne sekcije te se kroz tri sprovedena pokusa mijenjala razina vode na preljevnoj cijevi (definiranje razine gornje i donje vode) u oba spremnika te visina žmurja od dna eksperimentalne radne sekcije. Model iz prethodnog pokusa zamijenjen je žmurjem koje je sa desne strane imalo ugrađene piezometre postavljene na ravnoj horizontalnoj podlozi. Prikaz rezultata koji su dobiveni prilikom pokusa broj 5.2. (gdje su razine vode u lijevom spremniku iznosile $576 \mathrm{~mm}$, a u desnom spremniku $380 \mathrm{~mm}$, uz visinu otvora žmurja $60 \mathrm{~mm}$ od dna eksperimentalne radne sekcije) prikazan je na Slici 6.a). Zbog tehničkih poteškoća kod izvedbe modela temelja tlak u prvom piezometru (broj 20) nije prikazao zadovoljavajuće rezultate, dok su tlakovi u ostalim piezometrima zadovoljavajući. Na temelju tih poteškoća, razina vode u prvom piezometru pretpostavljena je kao najveća (386 mm). Na osnovi provedenih pokusa zaključeno je kako će tlak vode na temelj brane opadati onda kada se žmurje postavi na manju udaljenost od dna spremnika (kod manjih otvora žmurja u odnosu na dno eksperimentalne radne sekcije).
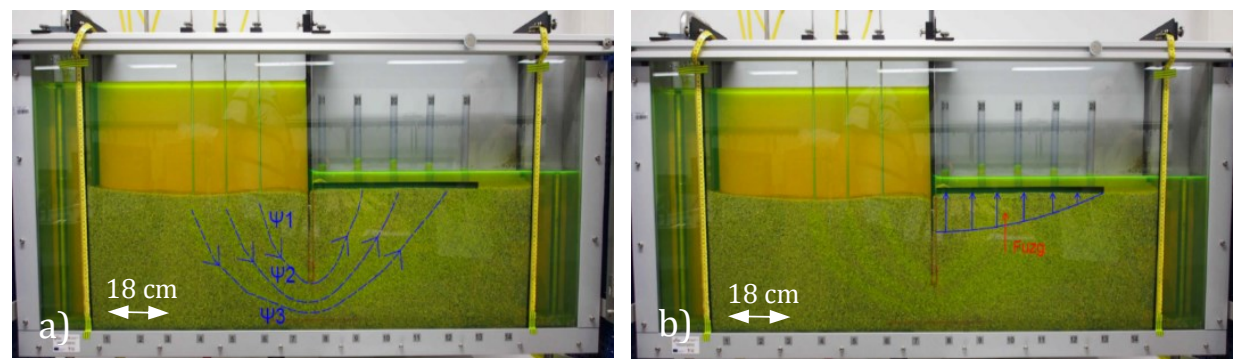

Slika 6. a) strujnice u pokusu 5.2., te b) dijagram tlaka na temelj brane [6]

Kada je model žmurja postavljen veoma plitko, potisak vode veći je od suprotstavljajuće težine materijala. Taj slučaj se naziva „hidrauličkim uzgonom". Dokaz hidrauličkog uzgona potrebno je provoditi kod svih hidrotehničkih objekata koji se nalaze u tlu sa velikim djelovanjem 
podzemnih voda jer se tom prilikom pojavljuju velike vrijednosti sila uzgona koje mogu stvoriti diferencijalno slijeganje na temelj brane. Rješenje je postavljanje većeg broja injekcijskih zavjesa ispod same brane. Na Slici 6.b) je prikazan dijagram tlaka i djelovanje sile uzgona na temelj brane.

\section{Analiza provedenih ispitivanja}

\subsection{Procjeđivanje podzemne vode kroz porozni materijal}

Prilikom provođenja Pokusa 1 (drenažni jarak - procjeđivanje kroz porozni materijal) cilj je bio odrediti strujnice i razviti ekvipotencijalnu (strujnu) mrežu. Nakon vidljivih tragova fluorescina kroz porozni materijal, grafički je izrađena strujna mreža sa mjerodavnim strujnicama (linije plave boje) i ekvipotencijalama (linije crvene boje), Slika 7.

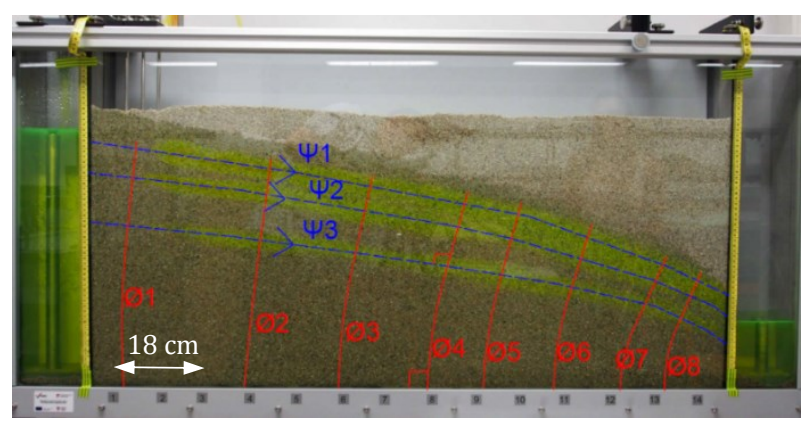

Slika 7. Strujna mreža na Pokusu 1 [6]

Linije zadovoljavaju uvjet međusobne ortogonalnosti. Razine, odnosno visine u Pokusu 1 su dane kroz Tablicu 1.

Tablica 1. Ulazni podaci za Pokus 1 [6]

\begin{tabular}{|c|c|c|c|}
\hline & $\begin{array}{c}\text { Razina vode u lijevom } \\
\text { gornjem spremniku } \\
\text { (komori), [mm] }\end{array}$ & $\begin{array}{c}\text { Razina vode u } \\
\text { desnom donjem } \\
\text { spremniku, }[\mathrm{mm}]\end{array}$ & $\begin{array}{c}\text { Visina sloja } \\
\text { pijeska, } \\
{[\mathrm{mm}]}\end{array}$ \\
\hline Pokus 1 & 478 & 183 & 500 \\
\hline Pokus 1.1 & 475 & 250 & 500 \\
\hline Pokus 1.2 & 477 & 290 & 500 \\
\hline
\end{tabular}

Prilikom provedbe pokusa cilj je bio mjeriti razine vode $u$ pojedinom piezometru, odnosno na piezometarskoj harfi te uvidjeti kako razina vode opada uzduž eksperimentalne radne sekcije kao posljedica smanjenja potencijalne energije od razine gornje do razine donje vode (Dijagram 1). Iz Dijagrama 1 se može zaključiti kako se pri razlici između razina gornje i donje vode, koja iznosi otprilike $190 \mathrm{~cm}$ za svaki pokus, pad piezometarske 
linije nelinearno smanjuje prema kraju s tendencijom da je pri kraju hidraulički gradijent nešto veći u odnosu na početak procjeđivanja.

Nakon izvedbe pokusa provedeni su proračuni kojima se može dokazati promjena hidrauličkog gradijenta po piezometrijskim točkama te uvidjeti kakve su bile brzine $\mathrm{u}$ istima. Hidraulički gradijent je izračunat prema formuli $I=\Delta H / \Delta L$ pri čemu je $\Delta H$ razlika potencijala (razlika između visina/razina vode u piezometrima), dok je $\Delta L$ duljina puta vode kroz tlo između svake mjerne točke (konstantna vrijednost od 0,09 m, međusobna udaljenost mjernih točaka na dnu eksperimentalne radne sekcije).

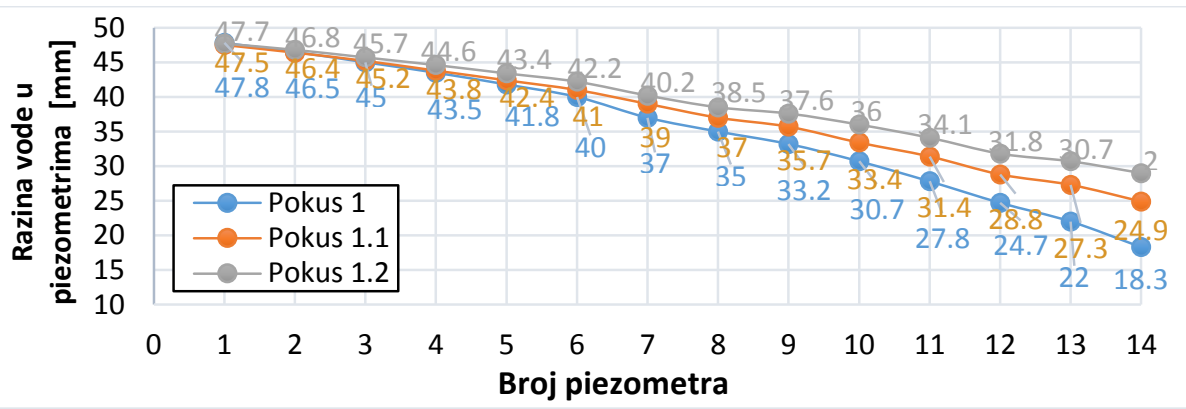

Dijagram 1. Prikaz pada razine vode u piezometrima, Pokus 1 [6]

Proračunom za sva tri pokusa utvrđeno je kako su brzine nezamjetno male, a hidraulički gradijent na pojedinim dionicama varira, Dijagram 2. Razlog manjim varijacijama hidrauličkog gradijenta je $u$ tome što se $u$ cjelokupnom filtarskom materijalu naišlo na nekoliko manjih oblutaka (promjera $4 \mathrm{~cm}$ ) koji su mjestimično promijenili vrijednost hidrauličkog gradijenta. Manja odstupanja u rezultatima hidrauličkog gradijenta mogu se pripisati i malom mjerilu fizikalnog modela, a time i nešto težeg preciznog očitanja razine vode u piezometrima.

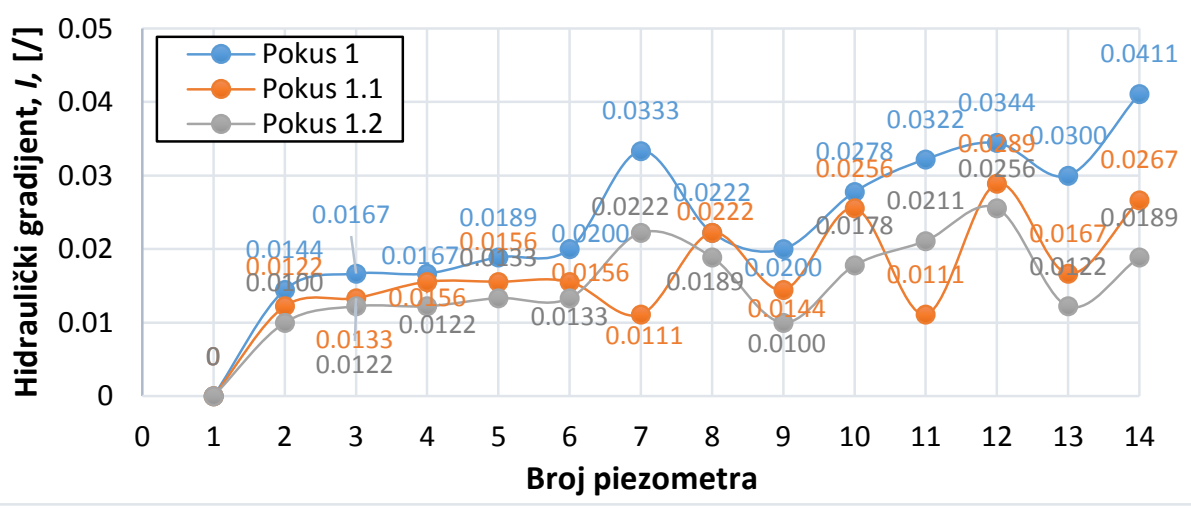

Dijagram 2. Prikaz iznosa hidrauličkog gradijenta po piezometarskim mjernim točkama [6] 


\subsection{Procjeđivanje kroz nasutu branu}

Cilj pokusa bio je odrediti linije protoka (strujnice) i razviti ekvipotencijalnu mrežu kao i u prethodnom slučaju. Razvijena strujna mreža zadovoljava uvjet ortogonalnosti, što je prikazano na Slici 8.

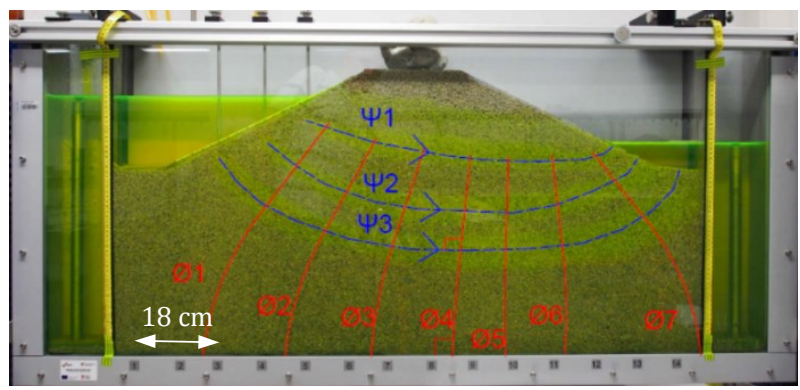

Slika 8. Strujna mreža za Pokus 2 [6]

Mjerenja razine vode u piezometarskoj harfi te proračun hidrauličkog gradijenta provedena su na isti način kao što je opisano u prethodnom dijelu rada, a rezultati za slučaj procjeđivanja kroz nasutu branu priloženi su u nastavku. Razine vode i visina pijeska u Pokusu 2 su dane u Tablici 2.

Tablica 2. Ulazni podaci za Pokus 2 [6]

\begin{tabular}{|c|c|c|c|c|c|}
\hline & $\begin{array}{c}\text { Razina vode } \\
\text { u lijevom } \\
\text { spremniku } \\
\text { gornje vode, } \\
{[\mathrm{mm}]}\end{array}$ & $\begin{array}{c}\text { Razina vode } \\
\text { u desnom } \\
\text { spremniku } \\
\text { donje vode, } \\
{[\mathrm{mm}]}\end{array}$ & $\begin{array}{c}\text { Visina sloja } \\
\text { pijeska sa lijeve } \\
\text { strane (prije } \\
\text { lijevog pokosa } \\
\text { brane) }[\mathrm{mm}]\end{array}$ & $\begin{array}{c}\text { Visina pijeska } \\
\text { sa desne strane } \\
\text { (nakon desnog } \\
\text { pokosa brane) } \\
{[\mathrm{mm}]}\end{array}$ & $\begin{array}{c}\text { Visina } \\
\text { kote } \\
\text { krune } \\
\text { brane, } \\
{[\mathrm{mm}]}\end{array}$ \\
\hline Pokus 2 & 533 & 432 & 350 & 350 & 560 \\
\hline Pokus 2.1 & 535 & 420 & 350 & 350 & 560 \\
\hline Pokus 2.2 & 573 & 457 & 350 & 350 & 560 \\
\hline
\end{tabular}

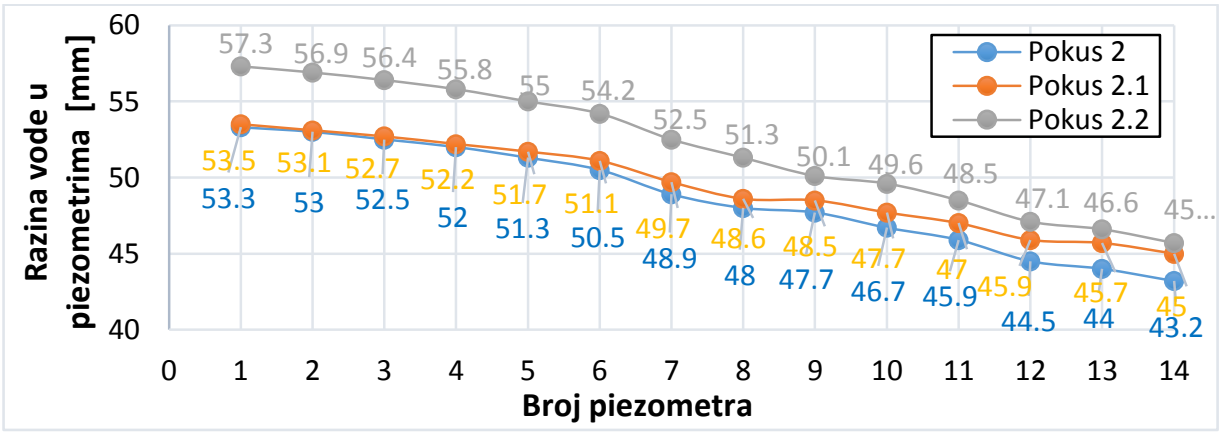

Dijagram 3. Prikaz promjena razina vode u piezometrima, Pokus 2 [6] 
Iz Dijagrama 3. se može uočiti kako se pad piezometarske linije uzduž toka blago smanjuje prema spremniku donje vode kao i u prethodnom slučaju, s time da su ovdje promjene puno blaže. Hidraulički gradijent se zbog prethodno definiranog problema pojave mjestimičnih kamenih oblutaka (žala) značajno mijenja uzduž toka procjeđivanja (Dijagram 4.).

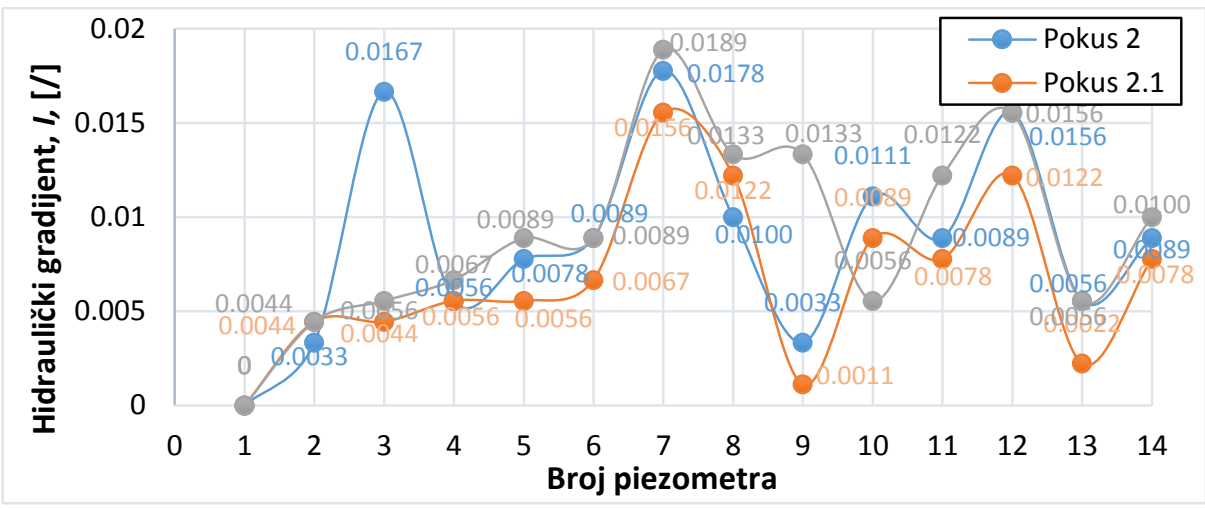

Dijagram 4. Prikaz promjena hidrauličkog gradijenta po piezometarskim mjernim točkama, Pokus 2 [6]

\subsection{Procjeđivanje ispod čeličnog žmurja}

Zadatak ovog pokusa bio je odrediti prikaz strujnica ispod žmurja, razviti strujnu mrežu te odrediti pritiske vode na dnu spremnika. Razvijena strujna mreža zadovoljava uvjet ortogonalnosti, Slika 9. Mjerodavne razine/visine u Pokusu 3 prikazane su kroz Tablicu 3.

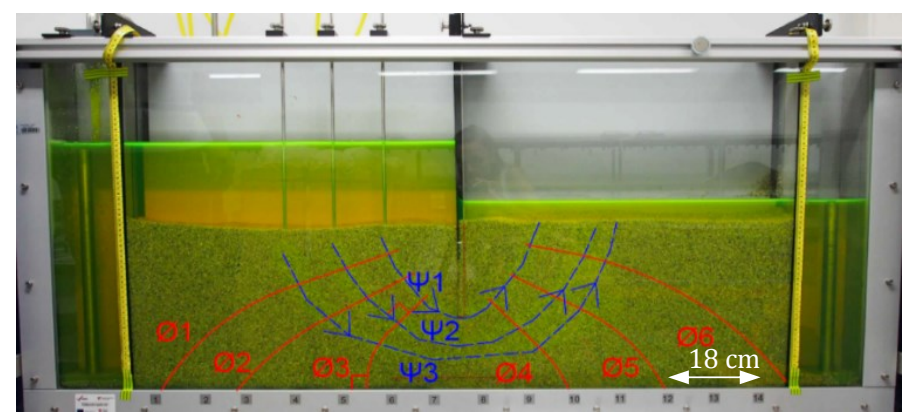

Slika 9. Strujna mreža na Pokusu 3 [6]

Prilikom provedbe ovoga pokusa nastojalo se analizirati izgled strujne mreže te uvidjeti promjene $\mathrm{u}$ razinama vode $\mathrm{u}$ piezometrima, kao i promjene hidrauličkog gradijenta primjenom različitih visina otvora čeličnog žmurja postavljenog od dna eksperimentalne radne sekcije pri različitim razinama gornje i donje vode. Na temelju rezultata provedenog pokusa dokazano je kako se razine vode u piezometrima nelinearno 
smanjuju prema spremniku donje vode (Dijagram 5.), dok hidraulički gradijent ponovno varira uzduž toka procjeđivanja (Dijagram 6.).

Tablica 3. Ulazni podaci za Pokus 3 [6]

\begin{tabular}{|c|c|c|c|c|}
\hline & $\begin{array}{c}\text { Razina vode u } \\
\text { lijevom } \\
\text { spremniku gornje } \\
\text { vode, [mm] }\end{array}$ & $\begin{array}{c}\text { Razina vode u } \\
\text { desnom } \\
\text { spremniku donje } \\
\text { vode, }[\mathrm{mm}]\end{array}$ & $\begin{array}{c}\text { Visina sloja pijeska } \\
\text { u eksperimentalnoj } \\
\text { radnoj sekciji, } \\
{[\mathrm{mm}]}\end{array}$ & $\begin{array}{c}\text { Visina žmurja od dna } \\
\text { eksperimentalne } \\
\text { radne sekcije, }[\mathrm{mm}]\end{array}$ \\
\hline Pokus 3 & 530 & 350 & 300 & 90 \\
\hline Pokus 3.1 & 533 & 350 & 300 & 120 \\
\hline Pokus 3.2 & 532 & 373 & 300 & 150 \\
\hline Pokus 3.3 & 549 & 375 & 300 & 150 \\
\hline Pokus 3.4 & 487 & 380 & 300 & 150 \\
\hline
\end{tabular}

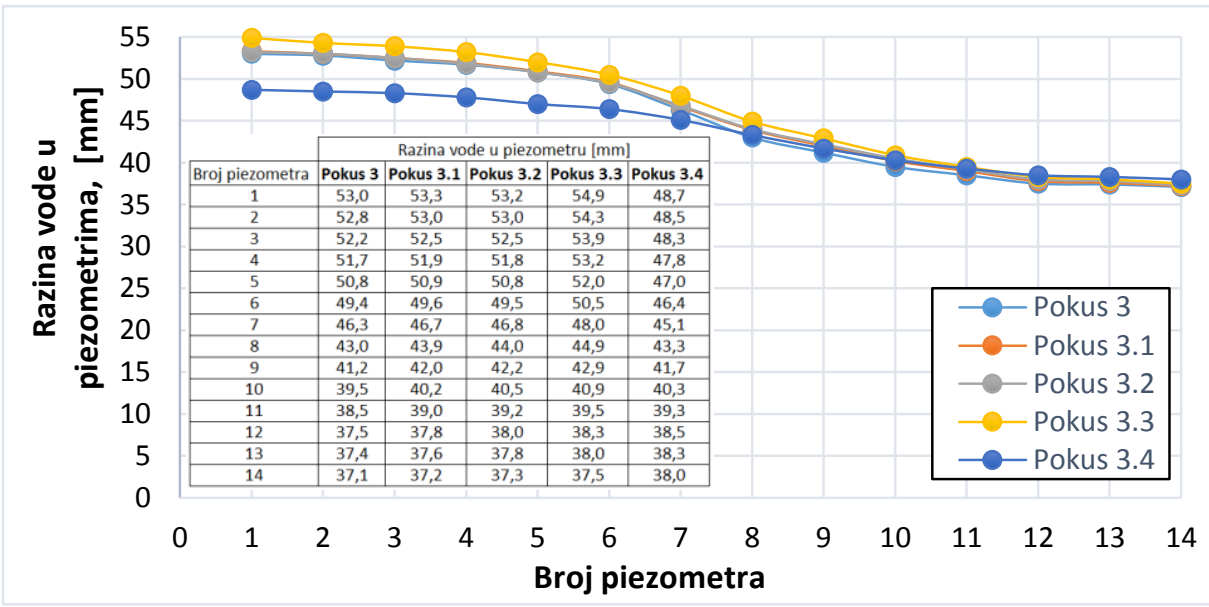

Dijagram 5. Promjene razina vode u piezometrima, Pokus 3 [6]

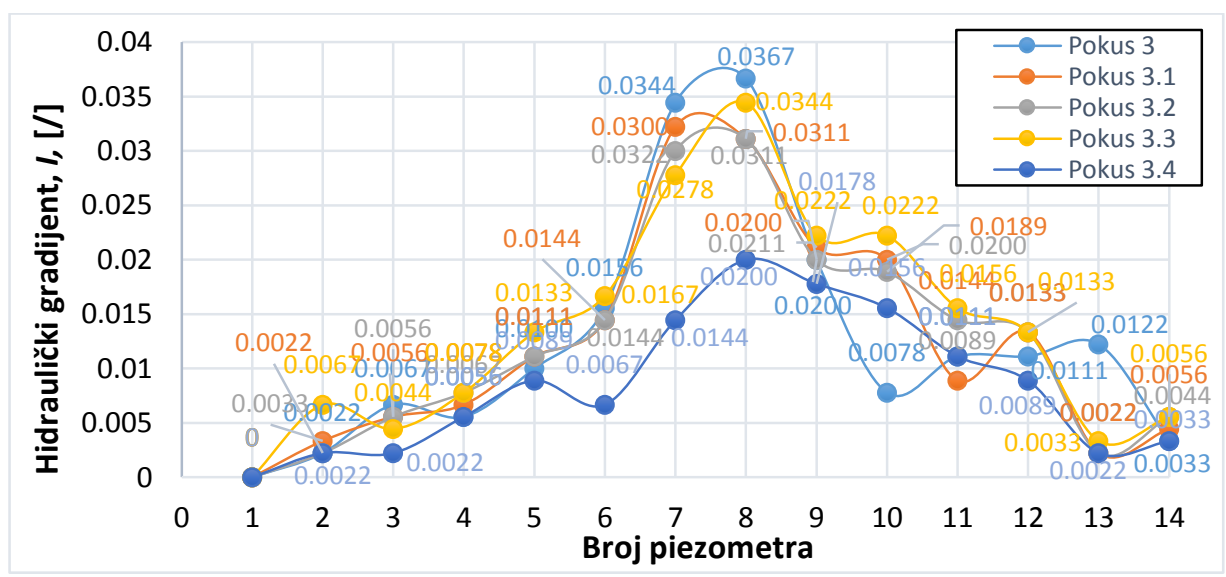

Dijagram 6. Promjene hidrauličkog gradijenta, Pokus 3 [6] 


\section{Zaključak}

U ovom radu analizirane su metode procjeđivanja vode ispod različitih prototipnih hidrotehničkih objekata iz svakodnevne prakse. Kroz analizu rezultata istraživanja eksperimentalnih pokusa dokazano je kako filtracija vode djeluje uvijek u smjeru toka te prolazi tik uz dno hidrotehničke građevine. U propusnim slojevima poput pijeska, koji se koristio u eksperimentima, jasno se prikazuju strujne linije, a ovisno o brzini toka vode oblikovati će se različite strujne mreže. Pored prikaza strujnica na fizikalnom modelu, uspješno su očitani i tlakovi u pojedinim točkama na dnu testiranog materijala (dnu eksperimentalne radne sekcije), što je za rezultat dalo vidljive promjene hidrauličkog gradijenta. Posljedično, mogu se u konačnici odrediti i brzine procjeđivanja u određenoj točki na prikazanom fizikalnom modelu. Uslijed rada na fizikalnom modelu HM169 treba voditi računa o pojavi mjehurića vode u piezometarskoj harfi te u cjevčicama sa tinkturom, a koji mogu sprječavati nesmetano očitavanje razine vode $\mathrm{u}$ piezometrima. Kod cjevčica s bojom se neprestano stvaraju manji mjehurići koji mogu stvoriti zaustavljanje toka boje te strujnica koja se formira u filtarskom sloju postaje isprekidana ili u trenucima debela i nepregledna. Problem se riješio neprestanim pritiskanjem cjevčica prstima.

Zahvala. Ovaj je članak rezultat rada u okviru projekta Razvoj istraživačke infrastrukture na Kampusu Sveučilišta u Rijeci (RC.2.2.06-0001), koji je sufinanciran iz Europskog fonda za regionalni razvoj (EFRR) $i$ Ministarstva znanosti, obrazovanja i sporta Republike Hrvatske.

\section{Literatura}

[1] Lončar, G., Andročec, V. (2003) Rukopis predavanja iz kolegija Mehanika fluida, Građevinski fakultet Sveučilišta u Zagrebu, Zagreb.

[2] Agroskin, I.I. (1969) Hidraulika, Tehnička knjiga, Zagreb.

[3] Žic, E., Ožanić, N., Karleuša, B. (2012) Mehanika fluida - teoretske osnove s riješenim zadacima, Skripta zadataka iz kolegija Hidromehanika, Građevinski fakultet Sveučilišta u Rijeci, Rijeka.

[4] Shaughnessy, E.J., Katz, I.M., Schaffer, J.P. (2005) Introduction to Fluid Mechanics, Oxford University, Oxford.

[5] Bukurov, M., Žic, E. (2017) Mehanika fluida - teoretske osnove, radni priručnik za potrebe studenata na kolegiju Mehanika fluida i Hidromehanika, Građevinski fakultet Sveučilišta u Rijeci, Rijeka.

[6] Reinić, I. (2018) Fizikalni model procjeđivanja vode ispod brane, završni rad iz kolegija Hidromehanika, Građevinski fakultet Rijeka, Rijeka.

[7] Gunt Hamburg. (10/2013) Visualisation of Seepage Flows - Experiment Instructions, priručnik za rad s fizikalnim modelom HM 169, Hamburg. 